\title{
Antinociceptive and Anti-Inflammatory Activities of Ethanol Extract of Bryophyllum Pinnatum Laboratory Animals
}

\author{
${ }^{1}$ Tanko Y., ${ }^{1}$ Mohammed A., Saleh M.I.A., ${ }^{1}$ Mohammed K.A., ${ }^{1}$ Etta E., \\ ${ }^{1}$ Bako I.G, ${ }^{1}$ Muhammad A, ${ }^{2}$ Yerima M, \\ ${ }^{I}$ Department of Human Physiology, Ahmadu Bello University, Zaria ,Nigeria \\ ${ }^{2}$ Department of Pharmacology and Clinical Pharmacy, Ahmadu Bello University, Zaria ,Nigeria
}

\begin{abstract}
The ethanol extract of Bryophyllum pinnatum was investigated for possible anti-nociceptive and anti-inflammatory effects in mice and rats was carried out using acetic acid-induced abdominal contractions in mice and formalin-induced hind paw edema in rats. . Three doses of the extract (50, 100, and 200mg/kg body weight) were used intraperitoneally for both anti-nociceptive and anti-inflammatory studies. There was a significant effect $(P<0.05)$ for the anti-nociceptive study, the highest activity resides at the lowest dose $50 \mathrm{mg} / \mathrm{kg}$ body weight of the extract, while for the anti-inflammatory study $(P<0.05)$ the activity resides more at the dose of $100 \mathrm{mg} / \mathrm{kg}$. Preliminary phytochemical screening of the extract revealed the presences of alkaloid, triterpenoid, saponin, glycerin, flavonoid,, glycerin and steroid. The intraperitoneal $L D_{50}$ is $774 \mathrm{mg} / \mathrm{kg}$ body weight in mice. The results support the local use of the plant in painful and inflammatory condition..
\end{abstract}

Key words: Bryophyllum pinnatum Anti-nociceptive; anti-inflammatory; Ethanol, Formalin, Acetic acid.

\section{Introduction}

Bryophyllum pinnatum was initially named kalanchoe. It belongs to the family, Crassulaceae. It has many common names such as air plant, life plant, resurrection plant, green love, Miracle leaf. It is widely naturalized in other parts of the world including tropical eastern Africa, Asia (e.g. Taiwan, Indonesia and New Guinea), New Zealand, south-eastern USA (i.e. Florida), the Caribbean, and the Pacific (i.e. the Galapagos Islands, Melanesia, Polynesia and Hawaii) (Biosecurity Queensland, 2011). The plant reproduces both from the seeds and vegetative from then bulbils at the margins[ 2 ] .

The herbal remedies of Bryophyllum pinnatum have been seen in various culture ,and still serves as the main means of therapeutic medical treatment and it is also used for all set of respiratory conditions ,kidney stones gastric ulcers, skin disorders ,promote menstruation [2, 3 ] In Bagbahera, the indigenes use the fresh leaves juice to repel mosquitors. They apply the juice on the infants body in order to protect them from mosquitoes bites[ 4 ]. Traditional healers in Northern part of Nigeria however claimed that the leaves and root serve effectively as an asthmatic remedy. It was claim to be useful for the treatment of other cardiovascular diseases [ 5$]$.

This research was aimed at investigating the possible anti-nociceptive and anti-inflammatory activities of ethanol extract of Bryophyllum pinnatumt in order to support or repute the claims by traditional herbalists.

\subsection{Location of Study}

\section{Materials And Methods}

The research was carried out in the Department of Human Physiology Faculty of Medicine, Ahmadu Bello University, Zaria,Nigeria.

\subsection{Drugs}

All chemicals and drugs used were obtained commercially and of analytical grade.

\subsection{Collection of Plant Material}

The plant Bryophyllum pinnatum was obtained from Department of plant science, Faculty of Agricultural science, Ahmadu Bello University,Zaria, Nigeria in the month of June 2012. It was identified at the herbarium unit of Biological Science Department, ABU, and Zaria, Nigeria by Mallam U.Galah, where a voucher specimen No.1838 has been deposited for future reference.

\subsection{Extraction of Plant Material}

The leaves were collected and dried under shade and ground into powder. The powder $(500 \mathrm{~g})$ was macerated in $30 \%$ of distilled water and $70 \%$ ethanol at room temperature for 24 hours. It was then filtered 
using a filtered paper (Whatman size No.1) and the filtrate evaporated to dryness in water bath at $37^{\circ} \mathrm{C}$. A brownish residue weighing $30.5 \mathrm{~g}$ was obtained. This was kept in air tight bottle in a refrigerator until use.

2.5. Phytochemical Screening

Standard screening test [6] were employed in the screening the extract for the different constituents.

\subsection{Animal Management}

Adult Wistar rats of both sexes weighing between $200-250 \mathrm{~g}$ and adult Swiss albino mice of both sexes weighing between $20-25 \mathrm{~g}$ were used for the experiment. They were kept in well ventilated room and fed with standard grower mash. Water was given ad libitum. This research was carried out in Ahmadu Bello University,Zaria, Nigeria in accordance with the rules governing the use of laboratory animals as accepted internationally.

\subsection{Acute toxicity study: $\mathrm{LD}_{\mathbf{5}}$}

\section{Experimental Procedures}

This was conducted by using the method of [ 7 ] In the first phase, mice were divided into 3 groups of three and treated with the ethanol extract of the plant at doses of 10,100 and 1000mg extract/ kg body weight intraperitoneally (i.p ) They were then observed for 24 hours.

In the second phase, mice were divided into 4 groups of one mouse each and treated with the ethanol extract at doses of 200, 400, 600 and $800 \mathrm{mg} / \mathrm{kg}$ body weight i.p. The $\mathrm{LD}_{50}$ was calculated using the second phase.

\subsection{Test for Anti-Nociceptive Study}

The Acetic acid induced writhing test in mice as described by [8 ] was employed. Swiss albino mice were divided into 4 groups of 5 mice each. The first group was given $10 \mathrm{ml} / \mathrm{kg}$ of Normal saline i.p. and served as control, groups 2, 3 and 4 received 50, 100 and $200 \mathrm{mg}$ of extract per $\mathrm{kg}$ of body weight i.p. respectively. Thirty minutes later, mice in all the groups were treated with Acetic acid $(0.6 \% \mathrm{v} / \mathrm{v}, 1 \mathrm{ml}$ per $100 \mathrm{~g}$ body weight i.p.). Five minutes after Acetic acid injection mice were placed in individual cage and the number of abdominal contractions was counted for each mouse for a period of 10 mins. Percentage inhibition of writhing was calculated using the formula

Inhibition $(\%)=$ Mean number of writhings(control)- Mean No. of writhings(test) $\times 100$

Mean number of writhing (control)

\subsection{Tests for Anti-Inflammatory Study}

The method used for this test was similar to that described by [9] and modified by [10 ] Adult wistar rats were dived into four groups of five rats each. Group 1 received distilled water as control group group 23 and 4 received 50,100 and $200 \mathrm{mg} / \mathrm{kg}$ extract Thirty minutes after treatment they were administered $50 \mu \mathrm{l}$ of $2.5 \% \mathrm{v} / \mathrm{v}$ solution of formalin, subcutaneously under the subplanter surface of the left hind paw. Oedema was assessed in terms of the difference in linear diameter at the injected paw and its diameter 1,2, 3, 4 and 5 hours interval after formalin injection.[11 ]. The degrees of inflammation and percentage inhibition of oedema were evaluated by measuring the paw diameter using vernier caliper [12 ]

Inhibition $(\%)=$ Mean paw diameter (control) - Mean paw diameter (treated ) x 100

Mean paw diameter (control)

\subsection{Statistical analysis}

Results were expressed as mean \pm standard error of mean (SEM). The data were statistically analyzed using the one-way ANOVA to determine whether results in a particular group were significantly different from those in the corresponding control groups. Results were statistically significant when $\mathrm{p}$ values is less than 0.05 $(\mathrm{P}<0.05)$ as described by [13].

\section{Result And Discussion}

\subsection{Phytochemical Analysis}

The freshly prepared extracts were subjected to preliminary phytochemical screening test for various constituents, which revealed the presence of alkaloids, triterpenoid, saponins, glycerin, flavonoids, glycerin and steroids. 


\subsection{Acute Toxicity Study $\left(\mathrm{LD}_{50}\right)$}

The sign of toxicity were first noticed after 2-3 hours of extract administration. There was decreased locomotor activity and decrease in sensitive to touch and jerking. Also there was decrease feed intake, tachypnoea and prostrations after 8 hours of extract administration.

The median lethal dose $\left(\mathrm{LD}_{50}\right)$ in mice was calculated to be $774 . \mathrm{mg} / \mathrm{kg}$ body weight.

\subsection{Anti-Nociceptive Study}

The extract at doses of 50,100 and 200mg/kg showed anti-nociceptive when compared to control (Fig 1). The extract decrease the number of acetic acid-induced abdominal constrictions in mice and the values were found to be significant $(\mathrm{P}<0.05)$. The activity resides more at $50 \mathrm{mg} / \mathrm{kg}$ with percentage inhibition of $61.3 \%$

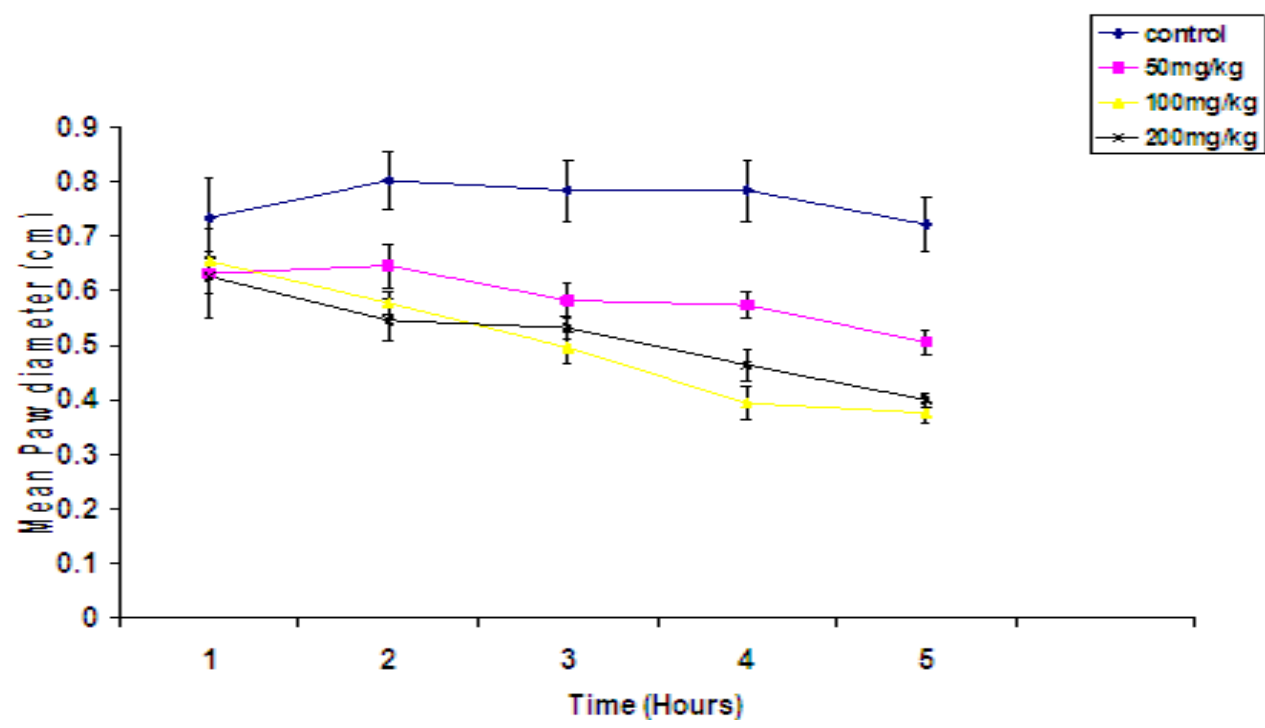

\section{Fig. 2 : Effect of Ethanolic Extract of Bryophy llum pinnatum on Formalin Induced Oedema in Rats.}

\subsection{Anti-Inflammatory Study}

The result of this experiment shown in Fig 2, showed the extract caused inhibition of formalin- induced oedema over a period of 1,2 34 and 5 hours respectively. The effect were not dose-dependent at the doses tested $(50,100$ and $200 \mathrm{mg} / \mathrm{kg})$. The peak inhibitory effects after 5 hours were observed with the dose of $100 \mathrm{mg} / \mathrm{kg}$. (34.4\%) Result were found to be statistically significant $(\mathrm{P}<0.05)$ in all the three doses when compared to control group.

\section{Discussion}

The ethanol extract of Bryophyllum pinnatum was found to have shown a significant $(\mathrm{P}<0.05)$ antinociceptive effect at all the doses tested. Although, the inhibitory effect on the acetic-induced writhings in mice was not dose- dependent, the percentage inhibition at a dose of $50 \mathrm{mg} / \mathrm{kg}$ body weight of extract was found to be highest $(67.1 \%$ ). ( Figure 1 ) The abdominal constriction method used in evaluating the activity anti nociceptive according to $[8,14]$ was a very sensitive one and can detect antinociceptive effect of substances at a dose that cannot be detected by other methods, such as the tail- flick test [15] Abdominal constriction responses were found to partly involve local peritoneal receptors[16]. The method has been associated with prostanoids in general, e.g increased levels of $\mathrm{PGE}_{2}$ and $\mathrm{PGF}_{2 \alpha}$ in peritoneal fluids $[17,18]$ as well as lipoxygenase products by some researchers $[19,20]$ Therefore, the result of the acetic acid-induced writhing strongly suggest that mechanism of action of this extract may be linked partly to lipoxygenases and / or cyclo-oxygenases. The activity demonstrated by the extract might be due to the presence of flavonoids and tannins that were present in the extract. This was supported by other workers who found that flavonoids and tannins were found to have antinociceptive and /or anti-inflammatory activities [21] 


\section{Anti-nociceptive And Anti-Inflammatory Activities Of Ethanol Extract Of Bryophyllum Pinnatum In Laboratory Animals}

The significant $(\mathrm{P}<0.05)$ anti-inflammatory activity exhibited by the extract at all the doses used $(50$, 100 , and $200 \mathrm{mg} / \mathrm{kg}$ body weight ) against oedema induced by formalin in rats compared to the control group the activity reside more at the dose $100 \mathrm{mg} / \mathrm{kg}$ body weight with percentage inhibition of $34.4 \%$ after 5 hours of extract administered .( Figure 2) The plant might serve as a useful source of anti-inflammatory agent. This antiinflammatory effect of the extract observed might be due to the presence of flavonoids, in the plant. This was supported by other workers, who found that flavonoids inhibit phosphodiesterases which are involved in cell activation, and their effect depend upon the biosynthesis of protein cytokines that mediate adhesion of circulating leucocytes to the sites of injuries This was supported by[22] that flavonoids and tannins were found to have anti-nociceptive and /or anti- inflammatory activities.

In conclusion, this study has shown that the ethanol extract of Bryophyllum pinnatum does possess significant anti-nociceptive and anti-inflammatory effects in the laboratory animal at the doses tested. The results support the traditional use of this plant in some painful and inflammatory conditions and also suggest the presence of biologically active principles which may worth further investigation and elucidation.

\section{Acknowledgement}

The authors wish to acknowledged the assistance of Mal Nuhu of the Department of pharmacognosy,A.B.U Zaria and Mal Bala Mohammed of Department of Human Physiology ,A.B.U Zaria.

\section{References}

[1] Biosecurity Queensland (2011). The University of Queensland. Special edition of Environmental Weeds of Australia for Biosecurity Queensland. http://www.dpi.qld.gov.au.

[2] Taylor, L (2003) :1 Herbal secret of rainforest $2^{\text {nd }}$ ed, sagca press Inc

[3] Gill, L.S.(1192): Ethonomedical uses of plant in Nigeria.

[4] Pankaj, O.(2003): Traditional medicine knowledge, natural occurrence and trade. Botanical composition. P 1-3..

[5] Sofowora ,A (1993): Medicinal plants and traditional medicine in Africa, $2^{\text {nd }}$ edition, John Wiley spectrum book limited, ibadan.pp 214-220.

[6] Trease, G.E., Evans, M.C.,( 1983) Textbook of pharmacognosy, $12^{\text {th }}$ ed Balliere, Tindall,

[7] London, pp.343-383.

[8] Lorke, D. (1983). A New Approach to Practical Acute Toxicity Testing, Arch. Toxicol, 53: $275-287$

[9] Koster, R; Anderson, M; Debeer, J. M. (1959). Acetic Acid used for Analgesic

[10] Screening, Federation Proceedings, 18: 412.

[11] Dubuisson, D., Dennis S.G., (1977): The formalin test: a quantitative study of the analgesic effect of morphine, meperidine a nd brain stem stimulation in rats and cats. Pain 4, 161-174.

[12] Tjolsen, A., Berge, O.G., Hunskaar, S., Rosland, J.H., Hole, K.,(1992) The formalin test:

[13] an evaluation of the method. Pain 51,5-17.

[14] Hess,S..M., and Milong R.C.(1972) Inflammation Mechanism and Control.Lepow. i.h. and Ward,P.A.ed, academic Press New York .p1-2.

[15] Winter, E. A. and Nuss, G. V., (1963). Anti-Inflammatory and antipyretic activities of

[16] indomethacin. Journal of pharmacology and Experimental Therapeutics. 141, $369-376$.

[17] Duncan, R. C; Knapp, R. G and Miller, M. C. (1977). Test of Hypotheses in population Means, In: Introductory Biostatistics for Health Sciences, John Wiley and Son, Inc. N. Y. pp. $71-76$.

[18] Gene, R.M., Segura, 1., Adzet, T., Marin, E., Inglesias, J., (1984) Heterotheca inuloides: anti-inflammatory and analgesic effects. Journal of Ethnopharmacology 60, 157-162.

[19] Collier, H. O. J; Dinneen, L. G; Johnson, C. A. and Schneider, C (1968). The Abdominal constriction response and its suppressesion by analgesic drugs in the mouse, Brit. J. Pharmacol; 32: $295-310$.

[20] Bentley, G. A. Newton, S. H. and Starr, J. (1981). Evidence for an action of morphine and the enkephallins can Sensory nerve endings in the mouse peritoneum, Brit. J. Pharmacol, 79: 125 - 134.

[21] Derardt, R ., Jougney, S., Delevaloee, F., Falhout, M., (1980): Release of prostaglandins E and F in an algogenic reaction and its inhibition. European Journal of pharmacology 51, 17-24.

[22] Levini, J.D., Lau, W.,M Kwait, G., Goetzl,E.J., (1984):Leukotriene B 4 produces

[23] hyperalgesia that is dependent on the polymorphonuclear leucocytes. Science 225, 743- 745

[24] Dhara, A.K., Suba, V., Sen, T., Pal, S., Nag Chaudhuri, A.K.,(2000) Preliminary studies on the anti-inflammatory and analgesic activity of the methanolic fraction of the root extract of tragia involucrate. Journal of Ethnopharmacology 72, 265-268.

[25] Duke, J.A (1992):: Handbook of Biologically Active Phytochemcials and their activities. CRC Press, Boca Raton, FL, pp. 22 - 25.

[26] Ahmadiani, A; Hosseiny, J; Semnanian, S; Javan, M; Saeedi, F; Kamalinejad, M and Sareni, S (2000). Anti-nociceptive and antiinflammatory effects of Eleagnus angustifolia fruits extract, J. Ethnopharmacol; 72: 287 - 292. 